\title{
Greywater Characteristics and Reuse in Tower Gardens in Peri-Urban Areas - Experiences of Kawaala, Kampala, Uganda
}

\author{
N. R. Kulabako ${ }^{\mathrm{a}, *}$, N.K.M. Ssonko ${ }^{\mathrm{b}}$ and J. Kinobe ${ }^{\mathrm{a}}$ \\ ${ }^{a}$ Department of Civil Engineering, Makerere University, P.O. Box 7062, Kampala, Uganda \\ ${ }^{b}$ Department of Development Studies, Uganda Christian University, P.O. Box 4, Mukono, Uganda
}

\begin{abstract}
This study was undertaken to create an understanding of greywater characteristics and to demonstrate a low cost reuse option involving application of small tower gardens for Greywater treatment and reuse in a peri-urban settlement, Kawaala in Kampala city, Uganda. To realise this, field surveys, greywater and soil sampling and analysis and, tower garden installation at selected households were undertaken. The common sources of greywater in Kawaala were found to be kitchen, bathroom and laundry with the majority of the households (72\%) pouring laundry water in open drains and spaces adjacent to their homes. The greywater generated in the area exhibited high $\mathrm{BOD}_{5}\left(71-873 \mathrm{mgL}^{-1}\right)$ and COD $\left(140-4886 \mathrm{mgL}^{-1}\right)$ and E.Coli $(<0-13900 \mathrm{cfu}$ per $100 \mathrm{~mL})$ values necessitating treatment prior to disposal in the environment. The greywater had low average $\mathrm{BOD}_{5} / \mathrm{COD}$ ratio $(<0.5)$ meaning that it is not easily treatable by biological means. Greywater application to the tower gardens, had limited impact on the soil potassium, organic matter and nitrogen content but increased the phosphorus content. The vegetables grown in the greywater towers thrived but were attacked by pests necessitating pest control. The households with the tower gardens appreciated the simplicity of the technology. To create demand for it requires sensitization and social marketing within the community. There is need to determine the hydraulic load of a tower garden to guide the number and size for a particular quantity of generated greywater for optimum performance. Also further monitoring is needed to ascertain the vegetable yield per soil volume, impact on crop growth and people's livelihoods.
\end{abstract}

Keywords: Greywater, Kampala, Peri-urban, Re-use, tower gardens, treatment.

\section{INTRODUCTION}

Greywater is water discharging from laundry, showers, bathtubs and kitchen sinks and is about $50-80 \%$ of residential wastewater [1]. Fresh water is becoming a rare resource in the world as a result of a variety of factors, the main ones being pollution and waste management. Studies have shown that in the next 50 years, more than $40 \%$ of the world's population will live in countries facing water scarcity especially in parts of Asia and Africa [2]. This has implications for human survival and the socio-economic development in these countries which calls for wise management of this resource. With increasing demand for freshwater, there is an urgent need for alternative water resources and optimization of water use efficiency through reuse options. Experiences elsewhere in the world indicates that greywater can be a cost effective alternative source of water. This is primarily related to its availability and low concentration of pollutants compared to the combined household wastewater [3].

In most cities in developing countries, the increasing urbanization has resulted in development of densely populated peri-settlements (slums). These settlements, inhabited by the

*Address correspondence to this author at the Department of Civil Engineering, Makerere University, P.O.Box 7062, Kampala, Uganda;

Tel/Fax: +256-41-4543152; E-mail address: rkulaba@tech.mak.ac.ug poor, have increased the demand for water supply [4]. However, the municipal authorities in most of these cities have limited capacity to provide basic services (adequate safe water, excreta, solid waste and greywater management) to these communities resulting in poor environmental sanitation [5]. The populations living in these settlements are therefore vulnerable to health risks given the increasing waste (solid and liquid) generation. In Kampala (capital of Uganda)'s periurban areas for example, greywater is indiscriminately disposed of in drainage channels and open spaces resulting in creation of malaria mosquito breeding grounds and smelly stagnant waters which are a health hazard particularly when children play in them and contaminate shallow groundwater sources [6]. The communities in the peri-urban settlements perceive greywater as being dirty and hence regard its reuse with disaffection [2]. However, appropriate reuse of greywater not only reduces agricultural use of drinking water and water costs, but also increases food security and improves public health [7]. Hence there is a need to promote its reuse in the peri-urban areas as it can be treated and used close to its origin thereby contributing to the Millennium Development Goals (MDGs) that have health and improving the lives of the people living in slums as a priority. It is noted that the main barrier for wider and faster dissemination of suitable greywater management systems at household level in the developing countries is the lack of knowledge and experi- 
ence [8]. Scientific knowledge is sparse regarding greywater characteristics allowing its reuse. Also, realising greywater reuse requires operational research which is pointed out as being important in implementing fundamental public health services effectively in slums [9].

Greywater needs some level of treatment prior to disposal to ensure minimal impacts on the environment. Greywater treatment does not aim at providing water for drinking but may be used for toilet flushing, laundry, lawn irrigation, window and car washing, groundwater recharge, agriculture or fire extinguishing [10]. In this paper, the focus is on greywater reuse in agriculture at a household level in densely populated settlements. This calls for low cost management and treatment systems. Small-scale and on-site treatment of greywater for this purpose includes either one or a combination of septic tanks, soil infiltration, drip irrigation and constructed wetlands. Septic tanks and soil infiltrations systems, though simple methods for on-site greywater treatment are problematic in the peri-urban areas with high water table due to potential for groundwater contamination. Constructed wetlands on the other hand require pre-treated greywater, can be expensive and need expertise for design, construction, operation and monitoring [7]. For greywater treatment, the technology of tower gardens was selected as it is a simple, innovative system, which uses greywater for growing vegetables on a small footprint $\left(<1 \mathrm{~m}^{2}\right)$ and can be easily self constructed with few local materials. Furthermore they are easy to operate and maintain and have been found to be appropriate in densely populated settlements for example in Kenya, Ethiopia and South Africa [11].

In Uganda, a previous study [12] undertaken in periurban settlements in Kitgum on tower gardens receiving Greywater had a positive uptake, with communities appreciating the benefits of Greywater reuse and being able to install these systems on their own after being taught how. However, in this study and all the others [11] application of tower gardens is still in its infancy necessitating a lot of scientific experimentation to determine their potential to make a real difference in the peri-urban areas. Here, information regarding the greywater characteristics, hydraulic load of a tower garden, grey water treatment potential and impacts on the vegetables and low cost pest control measures is still scarce. In this study therefore, an investigation into the reuse of Greywater for growing vegetables in tower gardens was undertaken in a selected peri-urban settlement in Kampala (Kawaala) city so as to provide a scientific basis for application of this option. The specific objectives of the study were 1) to determine the characteristics of the grey water generated by the communities in the settlement, 2) to assess the impacts of the Greywater on vegetable growth and soils within the tower gardens and 3) to ascertain communities' perspectives of this technology and impacts on their livelihood. The paper is part of this on-going study.

\section{STUDY AREA}

The study was undertaken in Kawaala Parish $\left(00^{\circ} 20^{\prime}\right.$ 24 ' $\mathrm{N}, 32^{\circ} 33^{\prime} 00^{\prime}$ ' $\mathrm{E}$ ) which is found in Rubaga division, within Kampala. It is located in the northern part of Kampala approximately $5 \mathrm{~km}$ from the city centre. The parish is predominantly a low-income peri-urban settlement (slum), with occasional middle-class residence among the low income deplorable housing. Most of the study area is a densely populated area with $76 \%$ of the area covered with informal settlements with limited social amenities such as schools, health services, drainage and waste management.

\section{MATERIALS AND METHODS}

\subsection{Field Surveys}

To ascertain the sanitation situation in the study area including water supply, excreta, solid waste and Greywater disposal and or reuse (if any), household surveys were undertaken. A total of 385 pre-tested questionnaires were administered.

\subsection{Selection and Sensitisation of Study Households}

The study households for which the tower gardens were installed were selected with the guidance of the community opinion leaders and criteria developed by the study team: willingness to have tower gardens on their land and space for the duration of the study, Greywater availability and readiness to operate the tower gardens. Three households were selected and these were sensitised on how Greywater could be utilised through agriculture and the associated potential benefits.

\subsection{Setting Up of the Tower Gardens}

One tower garden was set up at each of the selected households. These households were trained by the research team on how to set up the tower gardens as well as on the operation and maintenance aspects for effective performance. To demonstrate the effects of this irrigation/fertilisation method, a control tower garden was set up in exactly the same way as the other tower gardens and planted with the same vegetables. The control tower garden was to be irrigated with tap water instead of Greywater.

The tower garden setup was as described in [11]. A circle with a diameter of about $0.8 \mathrm{~m}$ was marked on the ground. This circle was excavated to a depth of about $0.5 \mathrm{~m}$ to form the bottom of the tower garden. Wooden poles $(2 \mathrm{~m}$ high $)$ were planted firmly into the surrounding bottom and a wire mesh was tied around the poles to create a cylindrical sleeve. After that, a bucket, with its bottom removed was placed in the middle of the poles. Stones were carefully packed in the centre of the modified bucket and the remaining space between the stones and bucket were filled with a soil mixture. The reason for placing the stones in the centre was to create a vertical column, for ensuring an even distribution of Greywater throughout the surrounding soil mixture. The soil mixture (to provide fertility) for all the tower gardens consisted of three parts of soil, two parts of animal (cow) manure and one part of ash measured by volume. The placed soil was then dampened and smoothened so as to provide cohesion but not compacted after reaching the upper rim of the bucket. After this, it was pulled out almost entirely in order to fill the inside again with stones and outside with the soil mixture. The same had to happen again with the wire mesh-it was also pulled upwards to the same level as the bucket. The whole procedure of filling and pulling the bucket and wire mesh upwards was repeated until a certain height of the 


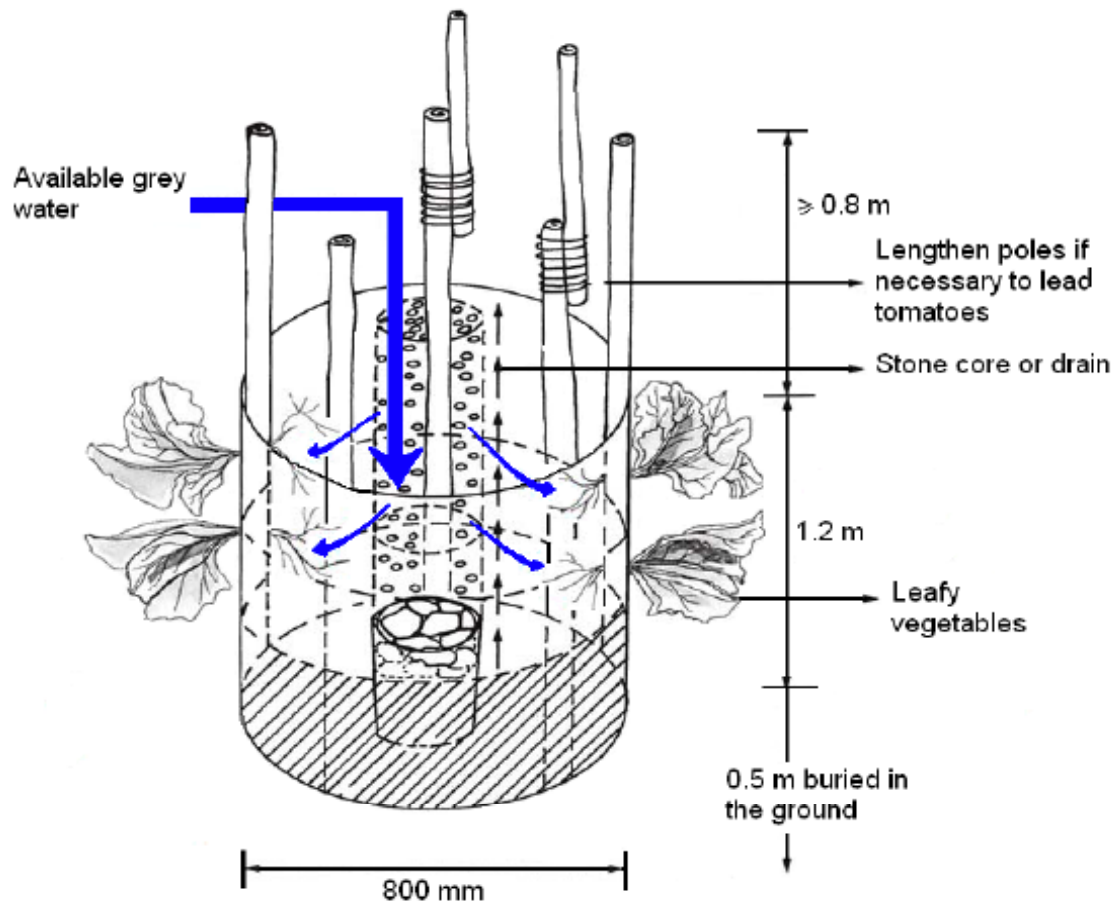

Fig. (1). The dimensions of the tower garden and feeding of the greywater (modified from [11])

tower garden (about $1 \mathrm{~m}$ from the ground surface) was reached (Fig.1).

\subsection{Tower Garden Operation}

The tower gardens were planted with the vegetables selected by the households: tomatoes, collard greens (sukuma wiki) and "buga" (Dioscorea fasciculate Roxb.). The tomatoes and "buga" were planted on top while the collard greens were planted through the holes in the side of the wire mesh cylinder. The holes in the sides were staggered diagonally so as to provide more space for root development.

The tower gardens were operated in such a way that the collected water from bathing and washing of clothes was applied on a daily basis. On average each tower garden received about 5-10L of Greywater per day. Over the weekend, about 10L of clean water (tap water) were applied to wash away the soap. The control tower garden meant to receive the tap water instead received Greywater.

\subsection{Greywater Sample Collection and Analysis}

To characterize the Greywater generated by the study households and applied to the tower gardens, samples were collected from the 3 households once a week separately for the 3 Greywater streams (kitchen, laundry and bathroom) for a period of 3 weeks. Physico-chemical and bacteriological analyses of the Greywater were determined for the selected parameters: pH, Dissolved Oxygen (DO), Electrical conductivity (EC), Temperature, Total Dissolved Solids (TDS), Turbidity, Chemical Oxygen Demand (COD), 5-day Biochemical Oxygen Demand $\left(\mathrm{BOD}_{5}\right)$, Ammonia-Nitrogen $\left(\mathrm{NH}_{3}-\mathrm{N}\right)$, Ortho-Phosphorus, Total Phosphorus, Sodium Adsorption Ratio (SAR) and E. Coli. The parameters pH, Temperature, DO and EC were determined in-situ using calibrated HANNA HI 991003 pH/Temperature, HANNA HI
9146 microprocessor DO meter and HANNA HI 9835 microprocessor conductivity/TDS meters, respectively.

Samples for physico-chemical and bacteriological analyses were collected in acid rinsed and sterilized bottles respectively, stored in a cool box at $4{ }^{\circ} \mathrm{C}$ and transported for analysis to the Public Health and Environmental Engineering Laboratory at Makerere University in Kampala. Prior to the analysis of ortho and total phosphorus, and ammonia nitrogen, the samples were filtered through a $1.2 \mu \mathrm{m}$ Whatman glass microfibre filter paper $(\mathrm{GF} / \mathrm{C})$. COD was determined using the Closed Reflux, Titrimetric method [13]. BOD 5 was determined by pressure difference within a closed system $\left(\mathrm{BOD}_{5} \mathrm{CW}_{7000}\right.$ direct reading apparatus) according to the instrument manual. Turbidity was determined using the attenuation radiation method [14]. Total phosphorus was determined using the ascorbic acid method with persulfate digestion while ortho phosphorus was measured using the ascorbic acid method [13]. $\mathrm{NH}_{3}-\mathrm{N}$ was determined using the Direct Nesslerization method [13]. Potassium, sodium, calcium and magnesium were determined using atomic absorption spectrometry (Perkin-Elmer 2380). Sodium Adsorption ratio was calculated from the measured concentrations of sodium, calcium and magnesium ions according to [15]. E.Coli determination was according to the membrane filtration technique using Chromocult agar [13].

\subsection{Soil Sample Collection and Analysis}

To ascertain the impact of the Greywater on the soils, three soil samples were collected at each household initially prior to Greywater application for determination of particle size distribution, $\mathrm{pH}$, organic matter content, nitrogen, phosphorus and potassium. After the application of Greywater, soil samples from the Greywater towers were later picked on a monthly basis for a period of 2 months and analysed for the 

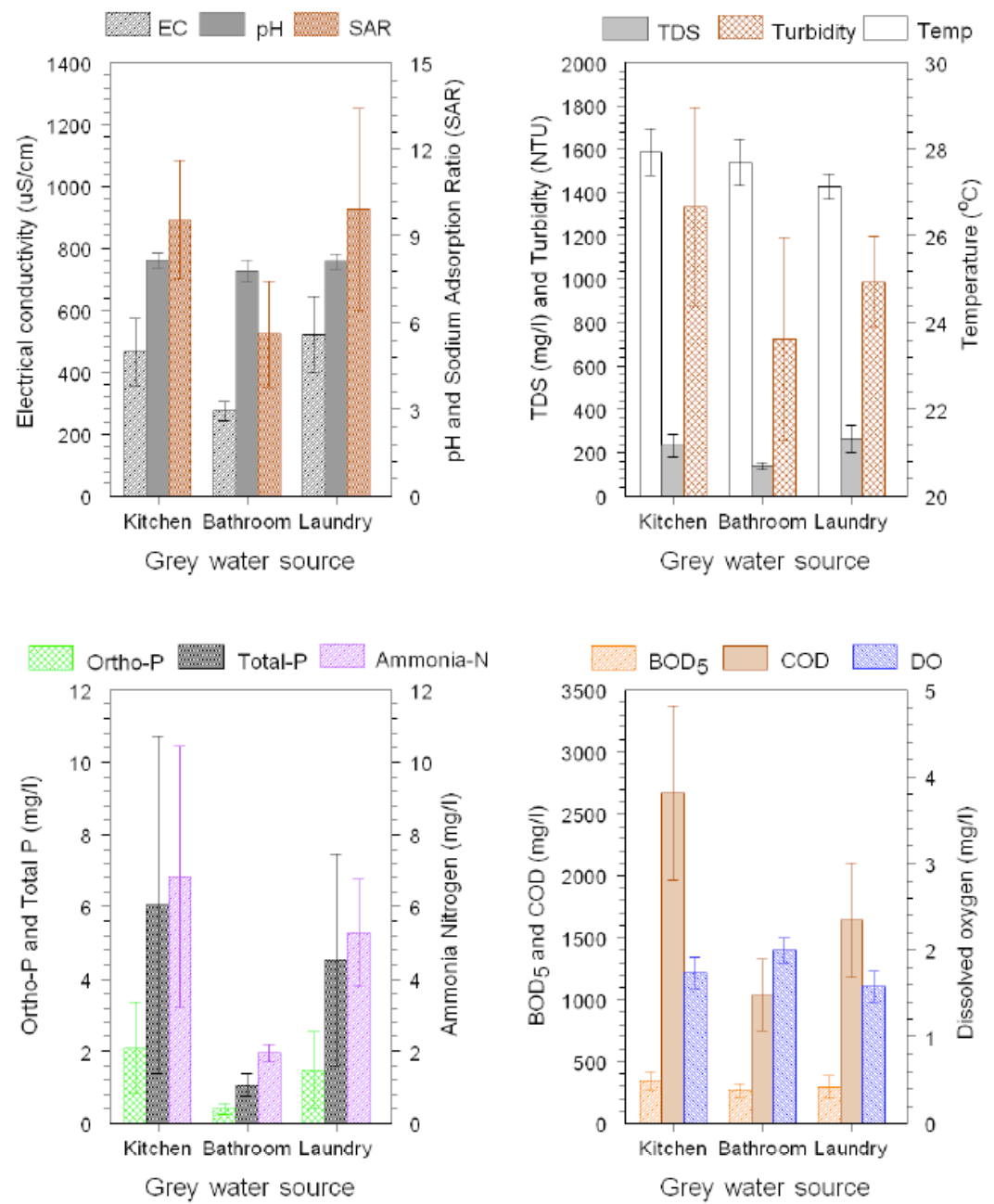

Fig. (2). Characteristics of greywater from the different sources in Kawaala (Bars represent mean values \pm 1 SE, $n=9$ per source).

aforementioned chemical parameters at the Soil Science Laboratory at Makerere University, Kampala, according to analytical techniques in [16]. $\mathrm{pH}$ was measured using the electrode method in a soil-water suspension using a 1:2:5 $(\mathrm{w} / \mathrm{v})$ ratio, organic matter determination was according to the Walkley and Black Method, Total nitrogen was analysed using the Kjeldahl method, potassium was determined by flame photometry method while measurement of phosphorus was according to the Bray method. A wet and dry sieve test was carried out to determine the particle size distribution [17].

\section{RESULTS AND DISCUSSION}

\subsection{Amount of Greywater Produced and Reuse}

The baseline survey revealed that most of the respondent households (69\%) had access to piped water while $29 \%$ relied on springs for domestic purposes including drinking. These findings are in line with previous studies in Kampala's informal settlements that have found springs to be an important source of water for the residents there [18, 19]. However, several of the springs in the area are unprotected and given the poor environmental sanitation, are vulnerable to contamination in these densely populated areas with implications for health of the communities [20,21].
The survey revealed that most of the respondent households (64\%) used 20-60L of water daily for washing, bathing, cooking and drinking. The daily per capita water consumption in the area was found to be in the region of 14-16L which is low and falls within the range $(5-20 \mathrm{~L})$ reported for Kampala's peri-urban settlements [22]. Given that the bulk of the area is unsewered (about $9 \%$ of the respondent households are connected to the sewer) the quantity of wastewater generated daily per household may be estimated to be $80 \%$ of the water consumption [23]. With this, approximately 16$48 \mathrm{~L}$ of wastewater is generated per household daily. The bulk of this wastewater $(>20 \mathrm{~L})$ is Greywater from laundry activities as articulated by $62 \%$ of the respondent households. The generated Greywater from the laundry and kitchen is disposed of in the compound and open storm water channels by the majority of the respondent households $(84 \%$ and $72 \%$ respectively). Regarding Greywater reuse, $>50 \%$ of the respondents said that they sometimes kept laundry water for reuse of which $>90 \%$ used it for cleaning their houses and $4 \%$ applied it to their gardens. $87 \%$ of the respondent households expressed willingness to reuse treated Greywater.

The respondent households had a relatively high level of awareness regarding the impacts of the poor wastewater dis- 
posal practices in the area. The problems reported in order of significance were wastewater stagnation that increases the community exposure to malaria, and waterborne diseases such as cholera, typhoid and diarrhoea.

\subsection{Greywater Characteristics}

\subsubsection{Physico-Chemical}

The results for the physico-chemical characteristics of the Greywater from the different sources are presented in Fig. (2). The results show some variation of the measured parameters between the different Greywater sources. The Greywater was moderately alkaline with the kitchen and laundry water having average $\mathrm{pH}$ values 8.15 and 8.12 respectively, which fall slightly outside the national effluent discharge standards i.e. 6-8 [24]. The relatively higher $\mathrm{pH}$ values of the kitchen and laundry water may be due to the alkalinity of the detergents and or soaps that are used [25]. The $\mathrm{pH}$ values of the Greywater are appropriate $(\mathrm{pH}<10)$ for irrigation [26]. The Sodium Adsorption Ratio (SAR) was higher in laundry water followed by kitchen and bathroom water in that order. The high laundry SAR values may be a result of the type of detergents or soaps used. SAR is an indicator of the salinity of the wastewater and is used for predicting the possible diverse effects of monovalent cations (sodium) in soils. The average SAR and EC values of the Greywater $\left(6-12\right.$ and $\left.<500 \mu \mathrm{Scm}^{-1}\right)$ when considered together imply that long term application of this Greywater can be detrimental to the hydraulic conductivity and physical properties of soils and associated plant systems [27]. Most commercially available bathroom/laundry products are currently manufactured using various types and quantities of sodium salts. Hence given the SAR values of the Greywater validates the need to apply freshwater to the Greywater towers as a control measure against soil damage (clogging) (section 3.4).

The temperature though relatively highest for the kitchen water was not so different from the bathroom and laundry water. The probable explanation for this could be that these waters were found outside for sampling and in situ measurements by the research team and hence it is possible that the temperature could more or less have adjusted to the ambient temperature at the time. All the source types exhibited high turbidity, with mean values greater than the stipulated national effluent discharge standard i.e. $>100$ NTU [24]. The kitchen waters had the highest turbidity most likely due to more soap use compared to that in the laundry and bathroom. During sample analysis the kitchen had a more cloudy (milky) appearance which was thought to result from more soap use. Turbidity in these wastewaters could also be related to the presence of high content of suspended solid material [3]. Here, possible high suspended solid material content was found in kitchen water followed by laundry water. The likely explanation may be the dirty laundry and kitchen utensils with the latter having food particles.

The average TDS content of kitchen, bathroom and laundry Greywater sources were generally within the national effluent discharge standards i.e. $<1000 \mathrm{mgL}^{-1}$ [24]. The total dissolved solids content of the Greywater types followed a similar trend to that of electrical conductivity with laundry water exhibiting higher values (Fig. 2). Despite this, the average EC and TDS values were $<0.7 \mathrm{dSm}^{-1}\left(700 \mathrm{uScm}^{-1}\right)$ and $<450 \mathrm{mgL}^{-1}$ respectively implying that the impact on crop water availability by these parameters in the Greywater generated in the area is none [27]. All the Greywater sources had mean phosphorus levels within the national effluent discharge standards (i.e. $<5$ and $10 \mathrm{mgL}^{-1}$ for Ortho and Total$\mathrm{P}$, respectively) as indicated in Fig. (2). The relatively higher total phosphorus levels in the kitchen and laundry water ( $>$ $3 \mathrm{mgL}^{-1}$ ) indicate that phosphorus containing detergents were used [2]. Although this is the most likely case (there is no law inhibiting the use of phosphate containing detergents in Uganda), phosphorus when disposed to the tower garden is not a problem because it is a plant nutrient. However, problems may accrue if the soils become phosphate saturated resulting in leaching to the groundwater and or to run-off to a surface water source. The mean ammonia nitrogen levels for the Greywater obtained here, were within the ranges $(<0.1$ $15 \mathrm{mgL}^{-1}$ ) reported for other studies in the developed countries with the Greywater in these cases considered light [28].

The Greywater types exhibited high mean $\mathrm{BOD}_{5}$ and COD values well above the national effluent discharge standards (i.e. $>30 \mathrm{mgL}^{-1}$ and $100 \mathrm{mgL}^{-1}$ respectively). The Greywater from the different sources, kitchen, bathroom and laundry had low $(<0.5)$ mean $\mathrm{BOD}_{5} / \mathrm{COD}$ ratios $(0.13,0.25$ and 0.17 respectively) within the low range $(0.25-0.64)$ reported in literature [10]. This implies that the wastewater is considered to be not easily treatable by biological means [29]. Whereas the mean $\mathrm{BOD}_{5}$ values for all the Greywater sources appear almost similar, the COD values were not, with the kitchen water having the highest value. This might be a result of the great use of detergents and or soaps in the kitchen [30]. The COD ranges for the different Greywater sources (kitchen: 140-4886; bathroom: 287-1904; laundry: 336-3101 $\mathrm{mgL}^{-1}$ ), were higher than values reported for the developed countries while for $\mathrm{BOD}_{5}$, except for the kitchen water (71-714 $\left.\mathrm{mgL}^{-1}\right)$ the ranges for the laundry (137$\left.873 \mathrm{mgL}^{-1}\right)$ and bathroom $\left(94-530 \mathrm{mgL}^{-1}\right)$ water were higher than reported values. The most likely explanation for this is the relatively low per capita water use in the area (section 4.1) resulting in high strength Greywater [31]. The bathroom water had a relatively higher mean DO level which was in line with the low $\mathrm{BOD}_{5}$ and $\mathrm{COD}$ values compared to the other Greywater sources. A possible explanation for this might be a relatively higher water use for bathing resulting in dilution [30].

\subsubsection{Bacteriological Characteristics}

E. Coli were used to characterize the bacteriological quality of the Greywater from the 3 sources (Table 1). The presence of E.Coli in all the Greywater sources is an indication of faecal contamination suggesting possible presence of pathogens. Kitchen water had E.Coli which could be a result of contaminated uncooked food and raw meat [3] and poor environmental sanitation from contaminated spring waters and children who frequently wash kitchen utensils with dirty and contaminated fingers [12]. That the Greywater contained E.Coli, suggests that it is a potential health risk with implications for safe reuse practices such as applying irrigation techniques, covering the soil with mulch, and avoiding contact with wet soil [2]. With respect to the tower gardens, the 
handling of the Greywater, proper application to the tower garden (Fig. 2) and not allowing Greywater to pool or stagnate as this will attract insects and rodents that may transmit disease and washing of hands after application are important.

Table 1. Bacteriological Quality (E.Coli) of the Greywater Source Types (n=3 Per Source; cfu/100ml)

\begin{tabular}{|c|c|c|c|}
\hline Greywater Source & Average Value & Median Value & Range \\
\hline \hline Kitchen & 53 & 30 & $<0-300$ \\
\hline Bathroom & 2817 & 150 & $<0-13900$ \\
\hline Laundry & 1014 & 190 & $<0-5800$ \\
\hline
\end{tabular}

\subsection{Soil Characteristics and Plant Growth Observations}

The soils used for the different tower gardens and chemical characteristics are presented in Table $\mathbf{2}$. The results indicated largely alkaline soils with high phosphorus $\left(>15 \mathrm{mgkg}^{-}\right.$ ${ }^{1}$ of dry soil) and low nitrogen, potassium and organic matter content. The application of Greywater on the tower garden increased the phosphorus content of the soil mixture compared to the impact on the rest of the parameters (Table 2). This may be explained by the nature of the soils used in the tower garden which consisted of a high proportion of smallsize particles (silts and clays) with high specific surface area that are noted to have a high sorption capacity for phosphorus [32].

Despite the Greywater containing ammonia-nitrogen (Fig. 2), the nitrogen content in the soils following Greywater application did not change much. This may be attributed to uptake by plants and also to a less degree, ammonia volatilization leading to loss to the atmosphere as nitrogen due to the relatively high $\mathrm{pH}(>7)$ values [33].

The observations of the planted vegetables revealed healthy growth of these. Unfortunately a comparison with the control tower garden was obstructed after the household where this had been installed started applying Greywater to it. When asked why this was done, the residents there were surprised that the planted vegetables receiving Greywater were doing well and hence they felt the urge to start applying Greywater to the tower garden. They did not appear to have appreciated why the control tower garden had been installed. One of the Tower gardens was seen to have a lot of houseflies which were thought to emanate from an adjacent pit latrine located about $<5 \mathrm{~m}$ away. This pointed to the need to site tower gardens at some appreciable distances from waste sources to minimize possible contamination of the planted vegetables from these. It was observed that the vegetables in most of the Greywater towers were attacked by pests, leading to stunted growth and or death as noted in a previous study [12]. To prevent this, pesticides were applied. Also according to [11], vegetables such as garlic and onions should be grown on the tower gardens as companion crops to facilitate biological control of pests and diseases. This was echoed by one of the households from their experience with gardening elsewhere. Also, animals were eating vegetables on the tower gardens and hence it was noted that this called for a need to erect a fence to protect the garden. The fence was erected by the landlord at no project cost indicating an appreciation and interest in the technology. The households with the tower gardens have had the neighbors applying their Greywater to the tower gardens and also harvesting the vegetables from these. Despite this, currently no other household besides the study households have installed their own tower gardens in the area.

\subsection{Practical Lessons Learned}

The interest of the respondents in the gardens is critical to their success. A case in point is where one of the respondents bought a fence to protect his garden from attack by animals. Also differentiating between the chemical content of the Greywater and non-Greywater is not obvious among the residents in these settlements which might have also contributed to the decision to apply Greywater on the control gardens. The slow uptake of the tower gardens among the residents in the area is most likely a result of the limited sensitisation on grey reuse and associated benefits as well as training on installation of the technology. Additionally, no social marketing was undertaken to create interest and demand for the technology. The tower gardens however, promoted a sense of neighbourhood in that the application of the Greywater and planted vegetables on maturing were shared with the neighbours without them.

\subsection{Conclusions}

The common sources of Greywater production in Kawaala are kitchen, bathroom and laundry. Greywater disposal infrastructure in Kawaala is poor with the majority of the households $(72 \%)$ pouring laundry water in open drains and spaces adjacent their homes. Laundry Greywater was mostly reused to clean houses and then disposed of.

The Greywater characteristics indicated waste with high $\mathrm{BOD}_{5}(>30 \mathrm{mg} / \mathrm{l})$ and COD $(>100 \mathrm{mg} \mathrm{COD} / \mathrm{l})$, E.Coli $(>0$ $\mathrm{cfu} / 100 \mathrm{ml}$ ) values necessitating treatment prior to disposal in the environment. Also with low $\mathrm{BOD}_{5} / \mathrm{COD}$ ratio $(<0.5)$, the Greywater is not easily treatable by biological means.

Greywater on application onto tower gardens resulted in an increase in the phosphorus content with limited impact on the potassium, organic matter and nitrogen content of the soils.

Tomatoes, collard green and "buga" plants grown in the tower gardens thrived with the Greywater. However, they were attacked by pests necessitating pesticide application. Pesticide use nonetheless has health and environmental impacts. This calls for awareness creation among the communities on the risks of pesticide use and hence importance of protection to safeguard health, crops, animals and water. Also communities should be encouraged to use biological measures for pest control such as growing of onions or garlic on the tower gardens as these limit the use of the potentially harmful pesticides.

The household occupants where tower gardens were installed appeared to appreciate the technology. However to create interest and demand so as to scale up this Greywater 
Table 2. Physical and Chemical (Initially and after Greywater Application) Soil Characteristics at the Different Tower Gardens (Average Values \pm SE; Initial: $\mathbf{n}=\mathbf{3}$; after Application: $\mathbf{n}=\mathbf{2}$ )

\begin{tabular}{|l|c|c|c|c|c|c|}
\hline \multirow{2}{*}{ Parameter } & \multicolumn{2}{|c|}{ Tower Garden 1 } & \multicolumn{2}{c|}{ Tower Garden 2 } & \multicolumn{2}{c|}{ Tower Garden 3 } \\
\cline { 2 - 7 } & Initial & After Application & Initial & After Application & Initial & After Application \\
\hline \hline Soil texture & \multicolumn{2}{|c|}{ Sandy silty clay } & \multicolumn{2}{c|}{ Sandy clayey silts } & \multicolumn{2}{c|}{ Clayey sandy silts } \\
\hline $\mathrm{pH}$ & $7.3 \pm 0.1$ & $7.9 \pm 0.2$ & $7.05 \pm 0.0$ & $8.08 \pm 0.3$ & $7.8 \pm 0.2$ & $8.45 \pm 0.27$ \\
\hline Nitrogen (\%) & $0.28 \pm 0.03$ & $0.28 \pm 0.07$ & $0.32 \pm 0.02$ & $0.3 \pm 0.08$ & $0.30 \pm 0.07$ & $0.57 \pm 0.12$ \\
\hline $\begin{array}{l}\text { Phosphorus (mgkg-1 of dry } \\
\text { soil) }\end{array}$ & $480 \pm 97$ & $622 \pm 179$ & $552 \pm 112$ & $707 \pm 273$ & $457 \pm 43$ & $1071 \pm 9$ \\
\hline $\begin{array}{l}\text { Potassium (meq per 100g dry } \\
\text { soil) }\end{array}$ & $2.092 \pm 0.32$ & $2.42 \pm 0.20$ & $3.66 \pm 0.83$ & $2.75 \pm 0.65$ & $4.71 \pm 0.90$ & $9.15 \pm 1.31$ \\
\hline Organic matter (\%) & $7.05 \pm 0.53$ & $6.61 \pm 1.20$ & $7.05 \pm 0.32$ & $6.62 \pm 1.44$ & $7.3 \pm 0.76$ & $11.75 \pm 1.85$ \\
\hline
\end{tabular}

reuse option necessitates increased sensitization and social marketing within the community on Greywater reuse and associated benefits.

There is need to determine the hydraulic load of a Greywater tower so as to guide the number and or size of gardens needed for a particular quantity of generated Greywater for optimum performance.

Also further monitoring of this Greywater reuse option is needed so as to ascertain the yield per volume of soil for each tower garden, impact of Greywater application on crop growth (hence need for a control) and people's livelihoods.

\section{ACKNOWLEDGEMENTS}

The authors are grateful to the Lake Victoria Research Initiative (VicRes) for supporting this work financially. Appreciation is expressed to the two anonymous reviewers whose comments and suggestions resulted in improvement of this paper.

\section{REFERENCES}

[1] O.R. Al-Jayyousi, "Greywater reuse: towards sustainable management", Desalination, vol. 156, pp. 181-192, August, 2003.

[2] World Health Organization (WHO).Guidelines for safe use of Wastewater, Excreta and Greywater, Volume 4: Excreta and Greywater use in agriculture. World Health Organization: Geneva, 2006.

[3] E. Eriksson, K. Auffarth, M. Henze and A. Ledin, "Characteristics of grey wastewater", Urban Water, vol. 4, pp. 85-104, March, 2002.

[4] United Nations (UN)-Water, "Coping with water scarcityChallenge of the twenty first century", 2007: Available from: http://www.fao.org/nrlwater/docs/scarcity.pdf [Accessed Oct. 13, 2010].

[5] K. Yusof and L. Kwai-Sim, "Urbanization and its effects on health in squatter areas", J. Human Ergol., vol. 19, pp. 171-184, December, 1990.

[6] R.N. Kulabako, M. Nalubega, E. Wozei and R. Thunvik, "Environmental health practices, constraints and possible interventions in peri-urban settlements- a review of Kampala, Uganda", Int. J. Environ. Health Res., vol. 20, pp. 231-257, July, 2010.

[7] A. Morel and S. Diener, Greywater Management in Low and Middle-Income Countries, Review of different treatment systems for households or neighborhoods. Swiss Federal Institute of Aquatic Science and Technology (Eawag): Dübendort 2006.

[8] B. Imhof, and J. Muhlemann, Greywater treatment on household level in developing countries: A state of the art review. Department of Environmental Sciences at the Swiss Federal Institute of Technology (ETH), Zurich, Switzerland, 2005.

[9] R.B. Patel, and T.F. Burke, "Urbanisation-an emerging humanitarian disaster", N. Engl. J. Med., vol. 368, pp. 741-743, December, 2009.

[10] B. Jefferson, A. Laine, S. Parsons, T. Stephenson, T. and S. Judd, "Technologies for domestic wastewater recycling", Urban Water, vol. 1, pp. 285-292, December, 2000

[11] C. Crosby, "Food from Used Water: Making the Previously Impossible Happen", 2005: Available from: http://www.dwaf.gov.zalBvents/lVaterWeek/2005/Documents/WaterWheelJan05d.pdf [Accessed Aug. 4, 2010].

[12] R. Kulabako, J. Kinobe, J. Mujunga, S. Olweny, and K, Sleytr, "Greywater use in peri-urban households in Kitgum, Uganda", Sustain. Sanitation Pract., vol. 1, pp. 16-24, 2009.

[13] American Public Health, American Water Works Association and Water Environment Federation (APHA/AWWA/WEF), Standard Methods for the examination of Water and Wastewater. APHA/AWWA/WEF United Press Inc, Baltimore, 1998.

[14] HACH, DR/4000 Spectrophotometer Procedure Manual. Hach Company, USA, 1999

[15] W. Alit, R. Zeev, W. Noam, A. Eilon, and G. Amit, "Potential changes in soil properties following irrigation with surfactant-rich greywater", Ecol. Eng., vol. 26, pp. 348-354, July, 2006.

[16] R. Okalebo, Laboratory methods of soil and plant analysis. A working manual Nairobi, Kenya, 2002.

[17] British Standards (BS) 1377, Methods of test for soils for civil engineering purposes. Part 2. British Standard (BS) Institution, London, 1990.

[18] AquaConsults, Identification of management options for improved water and sanitation services in informal settlements in Kampala, situation assessment report. Kampala: Water and Sanitation Programme (WSP) and National Water and Sewerage Corporation (NWSC), 2002.

[19] J. Muwuluke, "Planning sustainable sanitation systems: A case of human excreta management in peri-urban areas of Kampala", $\mathrm{PhD}$ Thesis, Makerere University, Kampala, Uganda, 2006.

[20] Kampala Urban Sanitation Project (KUSP), Surveillance of spring water sources in Kampala District. Chemiphar (U) Ltd and Hydraulic and Sanitation Consult for KUSP, Kampala City Council, 2006.

[21] G.W. Nasinyama, S.A. McEwen, J.B.Wilson, D. Waltner-Towers, C.L Gyles, and J. Opuda-Asibo, "Risk factors for acute diarrhea among inhabitants of Kampala District, Uganda", SA Med. J., vol. 90, pp. 891-898, September, 2000.

[22] National Water and Sewerage Corporation (NWSC), Sanitation strategy and master plan for Kampala city. Vol. 2. Main report. Beller Consult-Germany, Mott MacDonald-UK and M\&E Associates of Uganda for NWSC, Kampala, Uganda, 2004.

[23] A. Punimia, Wastewater Engineering (Including Air Pollution). Environmental Engineering-2. Laxmi Publications (P) Ltd., New Delhi, India, 1998 
[24] National Environmental Management Authority (NEMA), Environmental standards and preliminary environrnent impact assessment for wqter quality and discharge of effluent into water/land in Uganda. NEMA, Kampala, Uganda, 1999.

[25] D. Christova-Boal, R.E. Eden, and S. McFarlane, "An investigation into Greywater reuse for urban residential properties", Desalination, vol. 106, pp. 391-397, August, 1996.

[26] L. Abu Ghunmi, G. Zeeman, J. van Lier, and M. Fayyad, "Quantitative and qualitative characteristics of Greywater for reuse requirements and treatrnent alternatives: the case of Jordan", Water Sci. Technol., vol. 58, pp. 1385-1396, 2008.

[27] R.S. Ayers, and D.W. Westcot, Water quality for agriculture. Food and Agriculture Organisation (FAO) Irrigation and Drainage Paper 29, 1994.

[28] R. Birks, S. Hills, "Characterisation of indicator organisms and pathogens in Domestic Greywater for recycling", Environ. Monit. Assess., vol. 129, pp. 61-69, February, 2007.
[29] Metcalf and Eddy, lnc., Wastewater engineering: treatment and reuse. McGraw-Hill Companies, Inc., USA, 2003.

[30] L.L. Hernàndez, G. Zeeman, H. Temmink, and C. Buisman, "Characterisation and biological treatment of Greywater", Water Sci. Technol., vol. 56, pp. 193-200,2007.

[31] K. Carden, N. Armitage, K. V/inter, O. Sichone, U. Rivett, and J. Kahonde, "The use and disposal of Greywater in the non-sewered areas of South Africa: paper 1-Quantifying the Greywater generated and assessing its quality", Water SA, vol. 33, pp. 425-432, July, 2007.

[32] M.B. McGechan, and D.R. Lewis, "Sorption of Phosphorus by Soil, Part 1: Principles, Equations and Models", Biosyst. Eng., vol. 82, pp. I-24, May, 2002

[33] O.R. Zìmmo, N.P. van der Steen, H.J. Gijzen, "Comparison of ammonia volatilisation rates in algae and duckweed based waste stabilisation ponds treating domestic wastewater", Water Res., vol. 37, pp. 4587-4594, November, 2003.

Received: December 06, 2010

Revised: January 27, 2011

Accepted: January 29, 2011

(C) Kulabako et al.; Licensee Bentham Open.

This is an open access article licensed under the terms of the Creative Commons Attribution Non-Commercial License (http://creativecommons.org/licenses/by-nc/3.0/g) which permits unrestricted, non-commercial use, distribution and reproduction in any medium, provided the work is properly cited. 